\title{
American Corrections System Response to COVID-19: an Examination of the Procedures and Policies Used in Spring 2020
}

\section{Catherine D. Marcum ${ }^{1}$}

Received: 4 May 2020 / Accepted: 29 May 2020 /

Published online: 7 June 2020

(C) Southern Criminal Justice Association 2020

\begin{abstract}
This article will explore the federal and state correction system responses to COVID-19 as of early May 2020. Current statistics of infection rates and policy responses will be discussed. In addition, adjustments to inmate activities and staff will be reviewed, as well as responses by community corrections agencies.
\end{abstract}

Keywords COVID-19 $\cdot$ Corrections $\cdot$ Community corrections $\cdot$ Inmate

The Vera Institute of Justice (2020) released a statement on March 18, 2020 stating "it is not a matter of if, but when, the coronavirus show up in courts, jails, detention centers, prisons, and other places where the work of the criminal and immigration systems occur" (p. 1). This claim was not incorrect, as it has invaded prisons and jails across the nation. As of May 26, 2020, the Bureau of Prisons (2020a) reported 1577 federal inmates and 181 staff had contracted Coronavirus Disease 2019 (COVID-19). At that time, there were 136,959 inmates housed in the Bureau of Prisons managed institutions and 10,823 in community-based facilities, along with 36,000 staff. Furthermore, at the time of the above-referenced report, 3180 inmates and 413 staff recovered, and 64 inmates had died as a result of COVID-19.

States are experiencing varied rates of infection inside correctional facilities. Table 1 provides a compilation of the infection rates in state facilities as of May 27, 2020 as reported by their corrections' administration website. The state of Arkansas reported $38 \%$ of the state's total cases were concentrated in Cummins Prison (Budryk, 2020). Almost 4000 Ohio inmates contracted the virus as of late April 2020, notably reporting $78 \%$ of the inmates in Marion Correctional Institution were infected with COVID-19 (Bates, 2020). In early May 2020, the National Guard began assisting the Michigan

Catherine D. Marcum

marcumcm@appstate.edu

1 Department of Government and Justice Studies, Appalachian State University, PO Box 32107, Boone, NC 28608, USA 
Table 1 COVID-19 activity in state correctional facilities

\begin{tabular}{|c|c|c|c|}
\hline State & Inmates tested & $\begin{array}{l}\text { Confirmed COVID-19 } \\
\text { inmate cases }\end{array}$ & $\begin{array}{l}\text { Inmate (Presumed) } \\
\text { COVID-19 related deaths }\end{array}$ \\
\hline
\end{tabular}

\begin{tabular}{|c|c|c|c|}
\hline Alabama & 143 & 9 & 1 \\
\hline Alaska & 500 & 2 & - \\
\hline Arizona & 1071 & 182 & 6 \\
\hline Arkansas & - & 1246 & 2 \\
\hline California & 11,807 & 1216 & 9 \\
\hline Colorado & 3471 & 592 & 1 \\
\hline Connecticut & - & 792 & 6 \\
\hline Delaware & - & 121 & 6 \\
\hline Florida & 12,411 & 256 & 5 \\
\hline Georgia & - & 413 & 17 \\
\hline Hawaii & 18 & 0 & 0 \\
\hline Idaho & 47 & 0 & 0 \\
\hline Indiana & - & 683 & 16 \\
\hline Iowa & 1160 & 23 & - \\
\hline Kansas & - & 816 & 4 \\
\hline Kentucky & - & 359 & 2 \\
\hline Louisiana & - & 511 & 14 \\
\hline Maine & 494 & 4 & - \\
\hline Maryland & - & 133 & 6 \\
\hline Massachusetts & - & 500 & 8 \\
\hline Michigan & 38,227 & 3340 & 62 \\
\hline Minnesota & 2433 & 120 & 0 \\
\hline Mississippi & - & 27 & - \\
\hline Missouri & 614 & 45 & 1 \\
\hline Montana & - & 2 & - \\
\hline Nebraska & - & 1 & - \\
\hline Nevada & - & 9 & - \\
\hline New Hampshire & 15 & 0 & 0 \\
\hline New Jersey & - & 1481 & 42 \\
\hline New Mexico & - & 22 & - \\
\hline New York & & 492 & 16 \\
\hline North Carolina & 1369 & 648 & - \\
\hline North Dakota & - & 4 & 0 \\
\hline Ohio & 9098 & 4644 & - \\
\hline Oklahoma & 1479 & 2 & - \\
\hline Oregon & 532 & 149 & - \\
\hline Pennsylvania & 1969 & 236 & 6 \\
\hline Rhode Island & - & - & - \\
\hline South Carolina & - & 77 & - \\
\hline South Dakota & 90 & 3 & 0 \\
\hline Tennessee & 20,816 & 2657 & 4 \\
\hline
\end{tabular}


Table 1 (continued)

\begin{tabular}{llll}
\hline State & Inmates tested & $\begin{array}{l}\text { Confirmed COVID-19 } \\
\text { inmate cases }\end{array}$ & $\begin{array}{l}\text { Inmate (Presumed) } \\
\text { COVID-19 related deaths }\end{array}$ \\
\hline Texas & 50,183 & 2539 & 35 \\
Utah & 57 & 10 & 0 \\
Vermont & 464 & 48 & - \\
Virginia & - & 1149 & 6 \\
Washington & 443 & 40 & - \\
West Virginia & - & - & - \\
Wisconsin & 1316 & 64 & 0 \\
Wyoming & 0 & 0 & - \\
\hline
\end{tabular}

Information was gathered from the state correctional administration websites on May 27, 2020. Some data was missing from the websites

Department of Corrections with testing in several of their correctional facilities in the Upper Peninsula. In the state of Michigan, approximately 2000 inmates had tested positive for the virus and 41 inmates had passed due to complications (Graham \& The Associated Press, 2020).

Correctional facilities are by nature a physical environment where inmates are in constant close contact with one another, whether in cells or recreational areas, sharing the same ventilation system (James \& Foster, 2020). Compared to cruise ships and petri dishes in regard to the ease of sharing germs, correctional facilities contain areas (i.e., cells, recreation rooms, cafeterias) where it is extremely difficult to maintain distance and remain hygienic. Multiple past studies, prior to the emergence of COVID-19, found a significant relationship between residing in cell blocks and the spread of these infectious and communicable diseases in correctional facilities (Simpson, Simpson, Adily, Grant, \& Butler, 2019). Highly contagious illnesses, such as the flu and COVID-19, can easily be passed between inmates.

Much like the rest of the world, American federal and state correctional facilities launched into action to determine the best action plan for decreasing the spread of COVID-19. On March 23, 2020, the Center for Disease Control released a detailed form on interim guidance of the management of Coronavirus Disease 2019 (COVID19) for all correctional and detention facilities. The suggestions given to the American public, such as handwashing, staying six feet apart, and disinfecting household items, are often not feasible in a correctional setting (Morris, 2020, as cited in James \& Foster, 2020). Even the use of hand sanitizer is forbidden in most facilities due to the alcohol content (Francescani \& Barr, 2020). The options for correctional facility housing and daily activities are very limited, forcing inmates to spend a notable amount of time in close contact with others (Williams, Weiser, \& Rashbaum, 2020). As a result, correctional facilities have relied on other measures to decrease the spread of COVID-19.

This article will explore the federal and state correction system responses to COVID-19 as of early May 2020. It is important to keep in mind that while responses to the virus were fluid and changing on a daily basis, the most recent information reported on government websites and in the news media are presented in this piece. Adjustments to inmate activities and staff will be reviewed, as well as responses by community corrections agencies. 


\section{COVID-19 and Corrections Facilities}

\section{Visitation Regulations and Addressing Socialization Concerns}

A virus as contagious COVID-19 can be easily introduced to a correctional facility via the staff or with face-to-face visits with family, friends and legal counsel, all who could be exposed in environments outside the prison. As a result, the Bureau of Prisons (BOP) suspended all social visits for inmates until further notice (Bureau of Prisons, 2020b), and state governments have taken similar approaches. In order to attempt to maintain communication with loved ones and legal counsel, the federal and each state government are providing concessions. For example, each BOP inmate received 500 additional telephone minutes per month to allow for communication with individuals outside the correctional facility. Inmates in New York have been granted five free stamps per week and two free 30-min telephone calls per week (New York Department of Corrections and Community Supervision, 2020). Other concessions have been provided to lessen the stress of incarceration, such as providing the ability for family and friends to send post cards, video messages, and emails to the inmates. The state of Washington even approved a contract with Swank Motion Pictures to provide facilities with movies for inmate viewing (Department of Corrections Washington State, 2020).

Visits from legal counsel are essential for inmates to pursue civil liability and appeals cases during incarceration. However, the Bureau of Prisons suspended attorney visits for at least 30 days, upon which re-evaluation will occur once stay-at-home orders are lifted nationwide with states following suit (Bureau of Prisons, 2020b). The BOP and state correctional facilities do allow confidential legal calls via telephone and/or video platforms to ensure access to counsel. If an in-person legal visit is deemed a necessity, the attorney must undergo a health screening and temperature check before entry into a correctional facility (Bureau of Prisons, 2020b).

\section{Regulation of Inmate Movement}

The Bureau of Prisons, with state correctional administrative bodies following suit, have made efforts to regulate inmate movement within correctional facilities (Bureau of Prisons, 2020b). Staggered meal times and recreation times have been implemented to limit congregate gatherings. Internal facility inmate movements have been suspended overall, with some exceptions. For instance, transfers related to writs or Interstate Agreements on Detainers are still permitted, as well as transfers related to medical or mental health reasons. If a BOP inmate is transferred, the following conditions must be met:

1. Inmate must be in BOP custody for at least 14 days;

2. Regional directors must notify BOP Emergency Operations Center prior to movement of the inmate;

3. Exit screening performed for COVID-19 symptoms. If symptoms are exhibited (cough, shortness of breath and/or temperature of 100.4 degrees Fahrenheit or greater), the inmate will not be transferred and immediately placed in isolation. 
The BOP recognized that new inmates would be entering the system on a regular basis and would obviously require transfer approval. However, any newly-arrived BOP inmates will be screened for COVID-19 exposure risk factors and symptoms. If an inmate is asymptomatic with a risk of exposure, he/she will be quarantined. Inmates exhibiting symptoms will be isolated and tested for COVID-19 (Bureau of Prisons, 2020b).

\section{Facilitating Medical Services}

Many states have made concessions for inmate medical visits with the hopes of encouraging inmates to seek medical attention if they are experiencing symptoms and decrease the spread of COVID-19 through early detection (Prison Policy Initiative, 2020). States like Alabama, Minnesota, and West Virginia have suspended co-payments for incarcerated individuals as a result of the epidemic. Co-pays for inmates are usually between $\$ 2-5$, but this is an extreme cost for inmates who often make less than $\$ 1$ per hour (Prison Policy Initiative, 2020). Lower to no cost for a medical visit would hopefully decrease hesitation to seek medical attention and in turn, increase likelihood of early detection and diagnosis of COVID-19.

As of late April 2020, the BOP had obtained over 5000 test kits and multiple ventilators from local hospitals to assist with inmate treatment (Balsamo, 2020). However, treatment of infected inmate cases has come under fire by some of the families of those who are ill. For example, Michael Fleming's 59 year-old father, also named Michael, was serving 20 years at FCI Terminal Island in Los Angeles for drug conspiracy and contracted COVID-19 (Balsamo, 2020). According to Fleming, the family was never notified that his father's condition was worsening, even when he was hooked to a ventilator. They were unaware of his father's condition until the prison chaplain contacted the family asking how they would like his remains to be handled. California prison officials insisted they are following the guidelines set by the CDC and managing the prison population as efficiently as possible to stop the spread of the disease, but special circumstances arise depending on the situation.

\section{Change in Staff Protocol}

The COVID-19 outbreak also had a tremendous effect on the professional and personal lives of correctional staff in federal and state facilities due to the high potential for transmission of the virus by a staff member to a facility. In Bledsoe County, Tennessee, 583 of the 588 identified COVID-19 cases were from the Bledsoe Correctional Complex, with a high potential for the initial infection entering the facility originating from a staff member (according the facility's medical director) (Hutchinson, 2020). Staff in the state of Washington have been issued N95 respirators to wear during work hours Department of Corrections Washington State, 2020). With the exception of relocation travel, any planned travel by correctional staff nationwide has been suspended. If staff live in areas with "sustained community transmission," as indicated by the Center for Disease Control, they were directed to participate in daily temperature checks and self-reporting of exposure for at least the next 30 days (Center for Disease Control, 2020). The same requirement applied to outside contractors performing essential services or maintenance (all other contract work was suspended). 
Furthermore, volunteer visits have been suspended, with the exception of consideration of inmates who request access to a religious advisor.

\section{Consideration of Early Release for Low Level Offenders}

Many states have considered early release for low level offenders. On March 23, 2020, the New York Times reported the state of New Jersey was planning to release approximately 1000 individuals from its jails to decrease the risk of spread of Coronavirus Disease (COVID-19) (Tully, 2020). Offenders with probation violations and lowlevel crimes sentenced in Superior Court were those considered for release. Also, in late March 2020, the county jail in Houston, Texas, holding a population equivalent to "three cruise ships," stopped taking in individuals arrested for certain non-violent crimes (Aspinwall, Blakinger, Vansickle, \& Thompson, 2020). California Governor Gavin Newsom announced the intent to release up to 3500 inmates to parole supervision to lessen the prison population.

While lowering the population levels in jails and prisons could decrease the likelihood of spread of COVID-19, there are potential negative health repercussions to early release based on lack of housing. For instance, in Los Angeles County in California, approximately $30 \%$ of the jail population was homeless before incarceration (Williams et al., 2020). Returning to the streets will equate to a vulnerability for exposure the same as incarceration. Los Angeles recently reopened some of its recreation centers, formerly closed due to the COVID-19, to provide housing for homeless individuals.

\section{COVID-19 and Community Corrections}

The infiltration of COVID-19 into our criminal justice system has also affected our community corrections programming. With government buildings closed all over the nation, physical check-ins with probation and parole officers are suspended indefinitely to practice social distancing. States like Massachusetts have decreased the use of electronic monitoring as a supervisory tactic to avoid physical contact between the person fitting the device and the probationer or parolee. Probation and parole officers are using video and telephone calls to communicate with clients, rather than home or office visits (Schwartzapfel, 2020). While a seemingly reasonable alternative, there are potential barriers to prevent effective supervision. For example, the officer and supervised offender must both have reliable technology and Internet connection to maintain communication. Lack of finances and other resources can limit the ability to ensure successful remote supervision, as well as sporadic work schedules and personal circumstances.

Susan Rice, chief probation officer in Miami County, Indiana, called this community corrections adaptation to COVID-19 a "social experiment" (as cited in Schwartzapfel, 2020). Roles of the officers are evolving, responsibilities of the offenders are changing, and the success of these two melding together is yet to be determined. The inability to meet in person with supervised individuals loses the personal connections officers have with their clients, as well as the ability to monitor living environments and others in the household. The potential to identify potential risky behaviors or unsafe living conditions could be diminished. On the other hand, it may provide evidence of a more cost- 
effective method of supervision. Rather than spending time and mileage to travel to see supervised individuals, more check-ins per day can be accomplished via video chat or phone with less time and cost.

Rice's "social experiment" also involves the adaptation of probation and parole officers to their new job responsibilities as a result of COVID-19. The roles of the supervising officers are now expanding in many situations, requiring more time and effort to assist offenders with daily needs and living situations (Schwartzapfel, 2020). Probation and parole officers are also spending copious amounts of time helping clients file for unemployment and finding new resources, as many social support resources (e.g., Alcoholics and Narcotics Anonymous, counseling sessions, and education courses) are no longer physically meeting. While some have moved to virtual meetings, many do not have access to the technology to participate in the meetings or are unable to find meetings that work with their schedules.

Community corrections agencies in the United States are also using COVID-19 as an opportunity to revisit current sentencing policies. Brian Lovins, president-elect of the American Probation and Parole Association, stated "This gives us a big opportunity to challenge the need for incarceration of nonviolent folks" (as cited in Schwartzapfel, 2020). Probation and parole chiefs across the nation are calling for jurisdictions to strongly reconsider policies of jailing individuals for supervision violations. The NYU Marron Institute of Urban Management found some probation and parole departments are only doing drug testing in high risk cases and ceased arresting individuals for low level technical violations (Schwartzapfel, 2020). Community corrections stakeholders like Lovins are hoping for data that demonstrates successful community-based methods of supervision.

Efforts are also being made on the federal and state level to identify inmates at high risk for contraction of the virus and consideration of alternate placement in the community. On March 26, 2020, Attorney General William Barr sent a memorandum to BOP Director, Michael Carvajal, requesting the BOP utilize available statutory authorities to grant home confinement to eligible inmates who are at risk for COVID-19. As of May 3, 2020, an additional 1972 inmates had been placed on home confinement, equating to an increase of $69.1 \%$ (Bureau of Prisons, 2020a). The Coronavirus Aid, Relief and Economic Security Act (CARES Act, P.L. 116-136) provided assistance to multiple facets of the criminal justice systems, including the realm of community corrections, extending the amount of time a BOP inmate can be placed on home confinement when the Attorney General "finds that emergency conditions will materially affect the functioning" of its facilities (as cited in James \& Foster, 2020).

Even juvenile probation departments are reconsidering use of sanctions during the pandemic. Dozens of federal and state agencies across the nation have joined together to demand a moratorium on fees and fines (e.g., court costs, restitution) for juvenile probationers. Notable groups, such as the American Civil Liberties Union, Drug Policy Alliance, The Sentencing Project and National Association for the Advancement of Colored People, signed a petition along with state legal aids and juvenile resource centers to cease assessment and collections of fines and fees and provide notification to families of this change. In addition, these groups are requesting free video and telephone calls for juveniles who are in custody so they may communicate with family and friends, as well as providing free medical care and other resources (Berkeley Law Clinical Program, 2020). 


\section{Conclusion}

Currently, there are many unanswered questions about COVID-19, including best practices regarding detection and prevention in our correctional facilities. Of the approximate 3300 COVID-19 cases in four state correctional facilities (Arkansas, North Carolina, Ohio, and Virginia), $96 \%$ of those cases were asymptomatic (So \& Smith, 2020). This lack of continuity in symptoms makes it difficult to identify all contracted cases. While states like Texas with larger inmate populations are reporting less cases than smaller states (e.g., Ohio), it is important to keep in mind that the reported number of COVID-19 contracted cases is most likely substantially higher than reported as individuals who are asymptomatic or exhibiting minimal symptoms may not get tested.

One of the most proactive and efficient measures that should be taken is increased testing of staff and inmates in correctional facilities. Any individual who is exhibiting any of the symptoms associated with COVID-19 or has been exposed to someone with the virus should be tested. States like Michigan, Tennessee and California are beginning mass testing of inmates in some of their facilities to identify potential cases. Some facilities, such as Michigan's Lakeland Correctional Facility, houses many of the state's elderly inmates or those with underlying health conditions. Facilities such as these are moving to use proactive testing as much as possible to prevent spread and fatalities (So \& Smith, 2020), a trend that should be pushed as a nationwide policy.

Throughout this pandemic and time of crisis, government agencies have stepped up with massive financial opportunities to help support criminal justice agencies. On April 1,2020 , the Bureau of Justice Statistics made $\$ 850$ million available to public safety agencies struggling with response to COVID-19 (Department of Justice, 2020). The Coronavirus Emergency Supplemental Funding program was open for 60 days for local, state and tribal governments to apply for emergency assistance. These funds could be used, but were not limited to, the following requests: hiring personnel and paying overtime, inmate medical needs and necessary resources, and protective equipment. ${ }^{1}$ Later that month, the Office of Justice Programs (2020) announced almost $\$ 70$ million in grant availability to support adult and juvenile reentry. This funding will fund reentry programs focusing on agendas such as education, substance abuse, and community supervision.

As mentioned previously, this is a fluid situation for the entire world. Every day new information is released and decisions are made by government and private agencies, including our federal and state corrections system. At the time this piece was written, many states were still at stay at home orders and/or phasing into some form of economic reopening. It was yet to be determined if the rate of infection was stabilized, and while the hope is a continued decrease of infection rate with social distancing practices, the world awaits the fall season and potential spike. Much like other private and public entities, any lessening of restrictions and increase of freedoms for individuals under correctional control can be changed at any due to maintain the safety of the community and those supervised.

\footnotetext{
${ }^{1}$ At the time this manuscript was written in April 2020, multiple awards had been given to cities and states to assist with projects
} 


\section{References}

Aspinwall, C., Blakinger, K., Vansickle, A., \& Thompson, C. (2020, March). 21. The Marshall Project: Coronavirus transforming jails across the country. Retrieved from https:/www.themarshallproject. org/2020/03/21/coronavirus-transforming-jails-across-the-country.

Balsamo, M. (2020, April 29). Over $70 \%$ of tested inmates in federal prisons have COVID-19. AP News. Retrieved from https://apnews.com/fb43e3ebc447355a4f71e3563dbdca4f

Bates, J. (2020, April 22). Ohio began mass testing incarcerated people for COVID-19. The results paint a bleak picture for the U.S. prison system. Time.com. Retrieved from https://time.com/5825030/ohio-masstesting-prisons-coronavirus-outbreaks/

Berkeley Law Clinical Program. (2020, April 20). Call for nationwide moratorium on juvenile fees and fines. Retrieved from https://drive.google.com/file/d/1JmX2L9cArGxAL8yl4IjWolOB6XAQIFcz/view

Budryk, Z. (2020, April 21). 38 percent of Arkansas COVID-19 cases concentrated in state prison. TheHill.com. Retrieved from https://thehill.com/homenews/state-watch/493988-38-percent-of-arkansascovid-19-cases-concentrated-in-states-prison

Bureau of Prisons. (2020a). COVID-19 Coronavirus. Retrieved from https://www.bop.gov/coronavirus/

Bureau of Prisons. (2020b). BOP implementing modified operations. Retrieved from https://www.bop. gov/coronavirus/covid19 status.jsp

Center for Disease Control. (2020, March 23). Interim guidance on management of Coronavirus Disease 2019 (COVID-19) in correctional and detention facilities. Retrieved from https://www.cdc. gov/coronavirus/2019-ncov/downloads/guidance-correctional-detention.pdf

Department of Corrections State of Washington. (2020, April 14). Coronavirus/COVID-19 plan: Significant events timeline. Retrieved from https:/www.doc.wa.gov/news/2020/docs/daily-situation-report.pdf

Department of Justice. (2020, April 1). Department of Justice makes $\$ 850$ million available to help public agencies address COVID-19 pandemic. Department of Justice: Office of Public Affairs. Retrieved from https:/www.justice.gov/opa/pr/department-justice-makes-850-million-available-help-public-safetyagencies-address-covid-19?utm_campaign=justinfo\&utm_medium=email\&utm_source=govdelivery.

Francescani, C. \& Barr, L. (2020, March 19). Fearing outbreaks and riots, nation's prison and jail wardens scramble to respond to coronavirus threat. ABCNews. Retrieved from https://abcnews.go. $\mathrm{com} /$ Health/fearing-outbreaks-riots-nations-prison-jail-wardens-scramble/story?id=69676840

Graham, L. \& The Associated Press. (2020, May 3). More prisoners to be tested for COVID-19 with help from Michigan National Guard. Michigan Radio. Retrieved from https://www.michiganradio.org/post/moreprisoners-be-tested-covid-19-help-michigan-national-guard

Hutchinson, B. (2020, April 28). COVID-19 outbreak infecting over 500 prisoners may have come from staff: Medical director. ABCNews.com. Retrieved from https://abcnews.go.com/US/covid-19-outbreakinfecting-500-prisoners-staff-medical/story?id=70382322

James, N., \& Foster, M. (2020, April 2). Federal prisoners and COVID-19: Background and authority to grant release. In Congressional research service. Retrieved from https://crsreports.congress. gov/product/pdf/R/R46297.

Morris, M. (2020, March 6). Are our prisons and jails ready for COVID-19? American civil liberties union. Retrieved from https://www.aclu.org/news/prisoners-rights/are-our-prisons-and-jails-ready-for-covid-19/

New York Department of Corrections and Community Supervision. (2020) DOCCS COVID-19 Report. Retrieved from https://doccs.ny.gov/doccs-covid-19-report

Office of Justice Programs. (2020, April 6). Office of Justice Programs announces nearly \$70 million in grants available to support prisoners' successful reentry into their communities. Retrieved from https://www.ojp. gov/sites/g/files/xyckuh241/files/media/document/ojp-news-04062020a.pdf?utm_campaign= funding\&utm_content=reentry\&utm_medium $=$ email\&utm_source=govdelivery

Prison Policy Initiative. (2020, April 24). Response to the COVID-19 pandemic. Retrieved from https://www. prisonpolicy.org/virus/virusresponse.html

Schwartzapfel, B. (2020, April 3). Probation and parole officers are rethinking their rules as coronavirus spreads. The Marshall Project. Retrieved from https:/www.themarshallproject.org/2020/04/03/probationand-parole-officers-are-rethinking-their-rules-as-coronavirus-spreads

Simpson, P., Simpson, M., Adily, A., Grant, L., \& Butler, T. (2019). Prison cell spatial density and communicable diseases: A systematic review. BMJ Open, 1-10.

So, L. \& Smith, G. (2020, April 25). In four U.S. state prisons, nearly 3,300 inmates test positive for coronavirus - $96 \%$ without symptoms. Reuters.com. Retrieved https://www.reuters.com/article/ushealth-coronavirus-prisons-testing-in/in-four-u-s-state-prisons-nearly-3300-inmates-test-positive-for- 
coronavirus-96-without-symptoms-idUSKCN2270RX?fbclid=IwAR2jbHx9niKwYVBzhbU4 WGTOryaQT31B368TquC0C_R53AaC-DP4O_BUloI

Tully, T. (2020, March 23). 1,000 inmates will be released from N.J. to curb coronavirus risk. The New York Times. Retrieved from https:/www.nytimes.com/2020/03/23/nyregion/coronavirus-nj-inmates-release. html

Vera Institute of Justice. (2020, March 18). Guidance for preventive and responsive measures to Coronavirus for jails, prisons, immigration detention and youth facilities. Retrieved from https://www.vera. org/downloads/publications/coronavirus-guidance-jails-prisons-immigration-youth.pdf

Williams, T., Weiser, B., \& Rashbaum, W. (2020, March 31). 'Jails are petri-dishes': Inmates freed as the virus spreads behind bars. In The New York times Retrieved from https:/www.nytimes.com/2020/03/30 /us/coronavirus-prisons-jails.html.

Publisher's Note Springer Nature remains neutral with regard to jurisdictional claims in published maps and institutional affiliations.

Dr. Catherine D. Marcum is a professor of justice studies and the assistant chair in the Department of Government and Justice Studies at Appalachian State University. Her areas of expertise include correctional issues, cyber offending and victimization, and sexual victimization. She is currently the editor of Corrections: Policy, Practice and Research. 